\title{
Liver, Tumor and Viral Hepatitis: Key Players in the Complex Balance Between Tolerance and Immune Activation
}

\author{
Matti Sällberg* and Anna Pasetto \\ Division of Clinical Microbiology, Department of Laboratory Medicine, Karolinska Institutet, Stockholm, Sweden
}

Liver cancer is the third most common cause of cancer related death in the World. From an epidemiological point of view the risk factors associated to primary liver cancer are mainly viral hepatitis infection and alcohol consumption. Even though there is a clear correlation between liver inflammation, cirrhosis and cancer, other emerging liver diseases (like fatty liver) could also lead to liver cancer. Moreover, the liver is

\section{OPEN ACCESS}

Edited by:

Pranoti Mandrekar,

University of Massachusetts Medical

School, United States

Reviewed by:

Alessandra Franco,

University of California San Diego,

United States

Yochai Wolf,

Brigham and Women's Hospital and Harvard Medical School,

United States

*Correspondence:

Matti Sällberg

matti.sallberg@ki.se

Specialty section:

This article was submitted to Antigen Presenting Cell Biology,

a section of the journal

Frontiers in Immunology

Received: 04 November 2019

Accepted: 10 March 2020

Published: 27 March 2020

Citation:

Sällberg M and Pasetto A (2020)

Liver, Tumor and Viral Hepatitis: Key

Players in the Complex Balance

Between Tolerance and Immune

Activation. Front. Immunol. 11:552.

doi: 10.3389/fimmu.2020.00552 the major site of metastasis from colon, breast, ovarian and other cancers. In this review we will address the peculiar status of the liver as organ that has to balance between tolerance and immune activation. We will focus on macrophages and other key cellular components of the liver microenvironment that play a central role during tumor progression. We will also discuss how current and future therapies may affect the balance toward immune activation.

Keywords: liver, macrophage, T cell, T cell therapy, cancer

\section{INTRODUCTION}

The liver is a multi-tasking organ responsible for many crucial functions in the body. It is mostly known for its metabolic and detox work, in fact, it participates in the metabolism of fats (making bile), it stores and releases glucose and it clears harmful substances from the blood. The liver receives about $1.5 \mathrm{~L}$ of blood every minute coming from the digestive tract and its job is also to prevent and fight infections coming from the bloodstream. With such massive amount of blood, it is easy to imagine the countless potential antigens that the liver encounters at any given time. To prevent unnecessary inflammation and autoimmune disease the liver harbors different cellular components that work together with complex loops of interactions to maintain the organism homeostasis (1). Immune tolerance is therefore needed in the liver as safe measure to prevent tissue damage that would compromise the metabolic functions of this organ (2). The down side of this protective effect is that some infections, like viruses targeting hepatocytes (3) and even cancer have the possibility to escape the immune-response and give rise to potentially lethal liver diseases (47). A general view is that tolerance can be induced by both an insufficient/tolerogenic priming of effector T cells $(8,9)$ and directly through a regulatory T-cell response $(10,11)$. Kupffer cells, the specific tissue-resident macrophages of the liver, have a key role in promoting tolerance (12). This review will examine the major cellular components of the liver and tumor microenvironment, their role in controlling the balance between tolerance and activation and the potential therapeutic interventions to tilt the balance against liver cancer progression. 


\section{ANTIGEN PRESENTATION IN THE LIVER}

\section{Role of Kupffer Cells}

Kupffer cells (KCs) are liver-resident macrophages, they originate from fetal liver-derived erythromyeloid progenitors and their population is maintained by self-renewal and not by infiltrating monocytes (Figure 1; 13, 14). KCs are located in the hepatic sinusoid as represented in Figure 2, where pathogens enter the liver via portal or arterial circulation (15). The KC population represent a first line defense against infectious particles and potentially immune reactive particles entering the blood stream from the gut $(16,17)$. KCs express several scavenger receptors (18) such as Toll-like, complement, antibody receptors which allow them to activate danger-associated molecular patterns and internalize, and kill pathogens (15, 19). They also contribute to the initiation of an innate immune response by secretion of cytokines and chemokines (20). The KCs have a potent phagocytic activity not only for the above-mentioned blood-born pathogens but also for other particles/complexes/debris originating from dead erythrocytes and cells of the hepatic parenchyma. Other functions of KCs are related to the iron (21), bilirubin (22) and cholesterol metabolism (23).

The role of KCs in antigen presentation has been considered to be limited based on experiments where isolated mouse KCs only induced a low T-cell proliferation against soluble antigens in vitro (24). Other experimental in vivo set-ups (12) showed that $\mathrm{KC}$ were able not only to phagocytize particle-bound antigens but also subsequently induce a tolerogenic T-cell response against those antigens. This could be measured by induction of local T-cell proliferation, expansion of Foxp3 + IL-10 + OTII T regs in vivo. A high level expression of PDL-1 and secretion of IL-10 by KCs strongly suggests that this cell type can present antigens to $\mathrm{CD} 4+\mathrm{T}$ cells but then with the goal of inducing tolerance $(12,25)$.

It is important in this regard to keep in mind that KCs are not a homogenous population. As with other macrophagelike cells, two distinct subsets have been identified, one "M1 immunogenic" type that has phagocytic properties and secretes high levels of IL-12 and low levels of IL-10 (26) and another "M2 alternatively activated" type that secretes high levels of IL-10, TGF-b and low levels of IL-12 (27). When TLRs are engaged the KCs usually act as M2 type (28). When it comes to antigen presentation, several evidences implicate $\mathrm{KCs}$ as capable antigen presenting cells (APCs) but due to their up-regulation of inhibitory molecules like PD-L1 (29) and also Fas ligand (30) their major role is likely to be suppression $\mathrm{T}$ cell activation and induction of Tregs (10). The classification in M1 and M2 types is not exhaustive and does not reflect the complexity and diversity of functions among this cell population. Further subgrouping of the M2 type in M2a, M2b, and M2c has indeed been proposed. These subgroups express different markers and respond to different stimuli $(17,31)$. It is important to note that tumor-associated macrophages, which will be discussed later, have a M2 phenotype but a distinct transcriptional profile that promotes tumor angiogenesis $(17,32)$.

\section{Antigen Presentation by Other Cell Types}

A schematic representation of antigen presentation to CD4+ and CD8+ $\mathrm{T}$ cells is depicted in Figure 3. Kupffer cells are not the only cell type in the liver that function as APC but inducing tolerance instead of immune activation. Human hepatic myeloid dendritic cells (DC) (phenotypically characterized as $\mathrm{CD} 11 \mathrm{~b}+, \mathrm{CD} 11 \mathrm{c}+$, and CD1c+) secrete IL-10 and induce IL10 secretion by $\mathrm{T}$ cells (33) upon release by hepatic stromal cells of macrophage colony stimulating factor (34). Plasmacytoid DC (phenotypically characterized by expression of BDCA-2 and CD123) are also present in the liver and up-regulate PD-L1 in response to TLR agonists, promoting Treg cell differentiation (35, 36). Even though the liver APCs are skewed toward inducing tolerance there is also a population of myeloid DC (CD141+) that is able to cross-present antigen to CD8+ cells and induce IFN-g secretion $(37,38)$.

Other liver parenchymal cells also express MHC and costimulatory molecules and are capable of antigen presentation, although most of them still induce tolerance against the antigens presented. Endothelial cells, located at the liver sinusoids and termed liver sinusoidal endothelial cells (LSECs), promote tolerance in CD8+ T cells $(39,40)$ and lead CD4+ T cells toward Tregs differentiation (11) by secreting IL-10, TGF-b, PGE2 (41) and upregulating PD-L1 (42).

Hepatic stellate cells (HSCs) reside along the sinusoids and regulate the blood flow through these veins. HSCs can present antigens to $\mathrm{T}$ cells but again to promote Treg differentiation (43-45).

Lastly hepatocytes seem to be able to present antigens to $\mathrm{CD} 8+$ and $\mathrm{CD} 4+\mathrm{T}$ cells but fail to sustain their proliferation and induce apoptosis instead $(46,47)$.

\section{Viral Hepatitis Infection: Chronic Inflammation and Liver Cancer}

The three major viruses responsible for viral hepatitis are the hepatitis $B$ virus (HBV), the hepatitis $C$ virus (HCV), and the hepatitis D virus (HDV), each estimated to be chronically infect 257 milion, 140 milion, and 15 milion people worldwide, respectively (48). While the viruses are quite different as HBV is a double stranded-DNA virus belonging to the Hepadnaviridae family, $\mathrm{HCV}$ is a single-stranded + RNA virus belonging to the Flaviviridae family, and HDV a single stranded circular -RNA viroid, they share common pathological paths. All viruses infect hepatocytes but are not directly cytolytic, the cell damage in fact is due to the anti-viral immune response, such as direct killing by cytotoxic CD8+ T cells or NK cells (49) or the action of inflammatory cytokines (50). During immune activation, liver resident APCs can activate virus-specific $\mathrm{T}$ cells which are then responsible for recognition and killing of infected hepatocytes and secretion of inflammatory cytokines (50). Acute hepatitis is associated with viral clearance in $95 \%$ of $\mathrm{HBV}$ infections in adults but only $5 \%$ of vertical infections, and in about (49). $25 \%$ of HCV infections For HDV, a satellite virus to HBV, acute infections occur when HBV and HDV coinfect a host (clearance rate is 95\%), whereas most become chronically infected by HDV when appearing as a superinfection of HBV carriers. When viral 


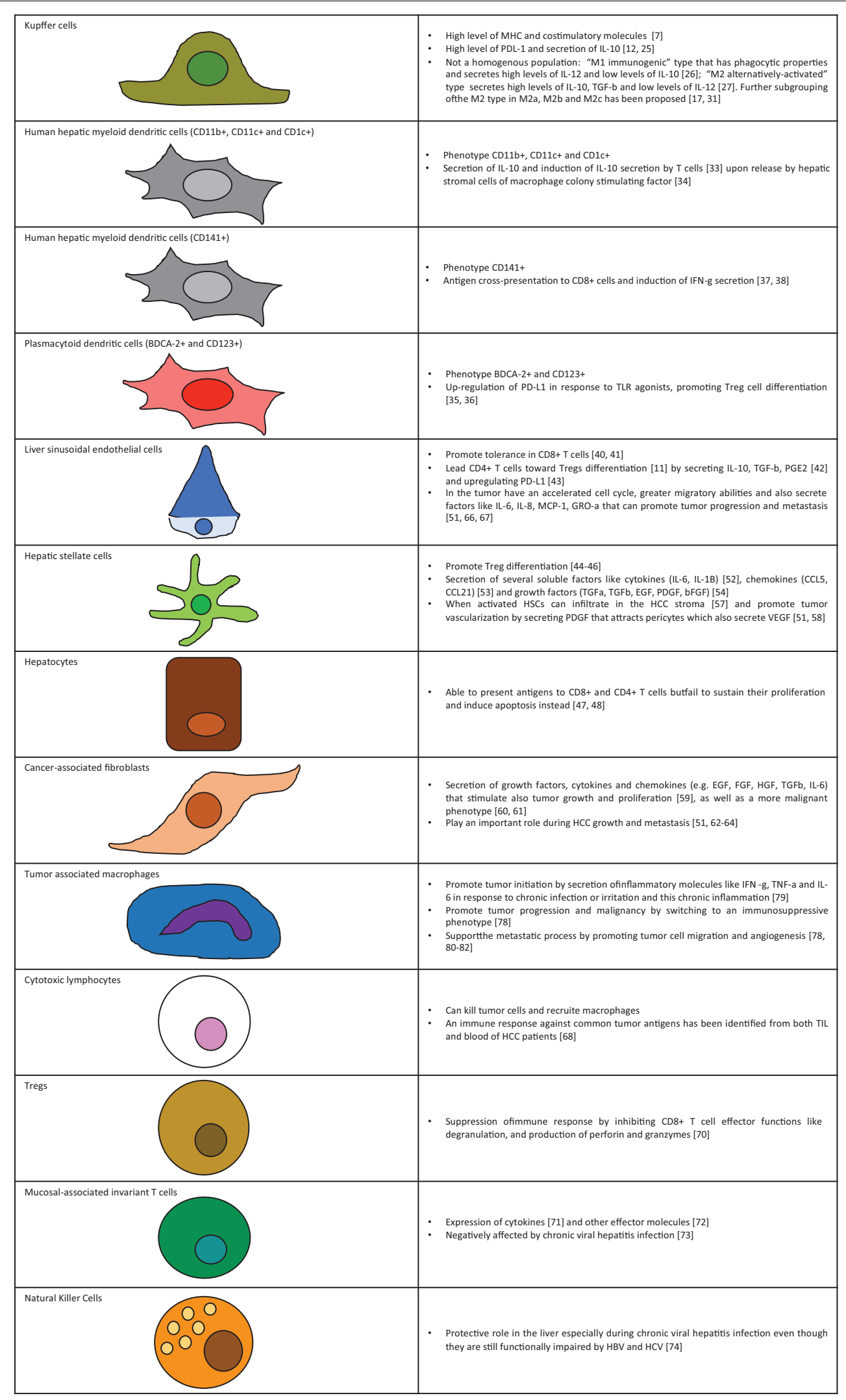

FIGURE 1 | Key cellular components of liver tumor microenvironment. Schematic representation of cell types and summary of functions in tumor microenvironment. 


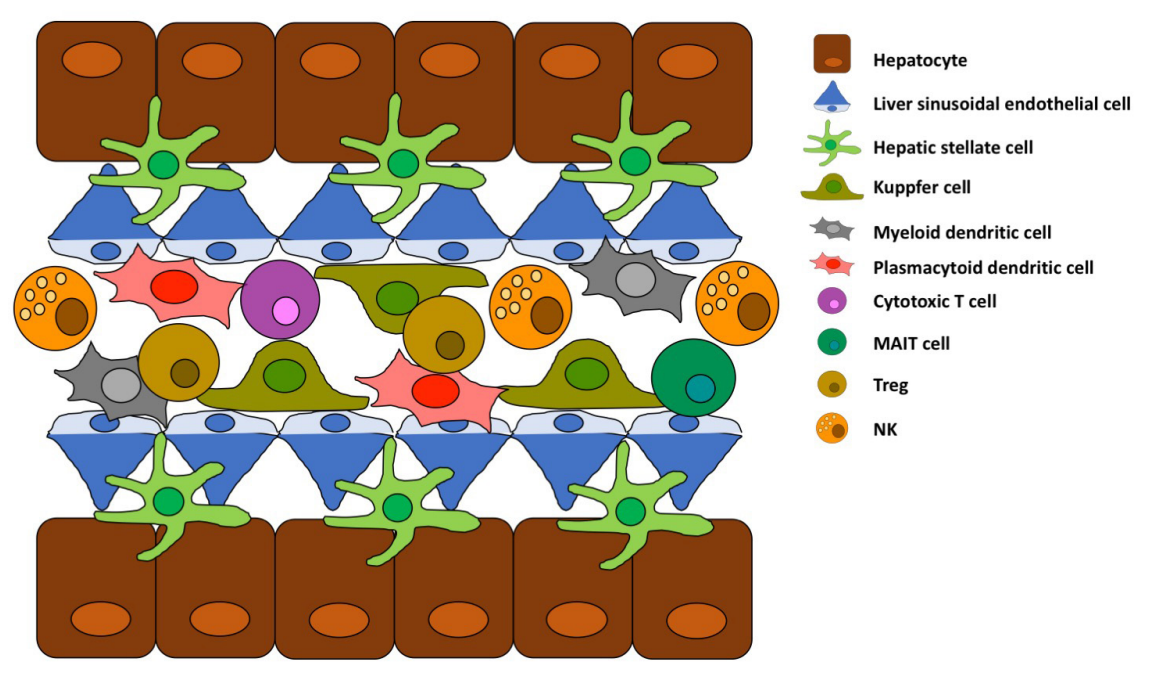

FIGURE 2 | Schematic structure of liver sinusoid. Key cell types and their spatial location are schematically represented.

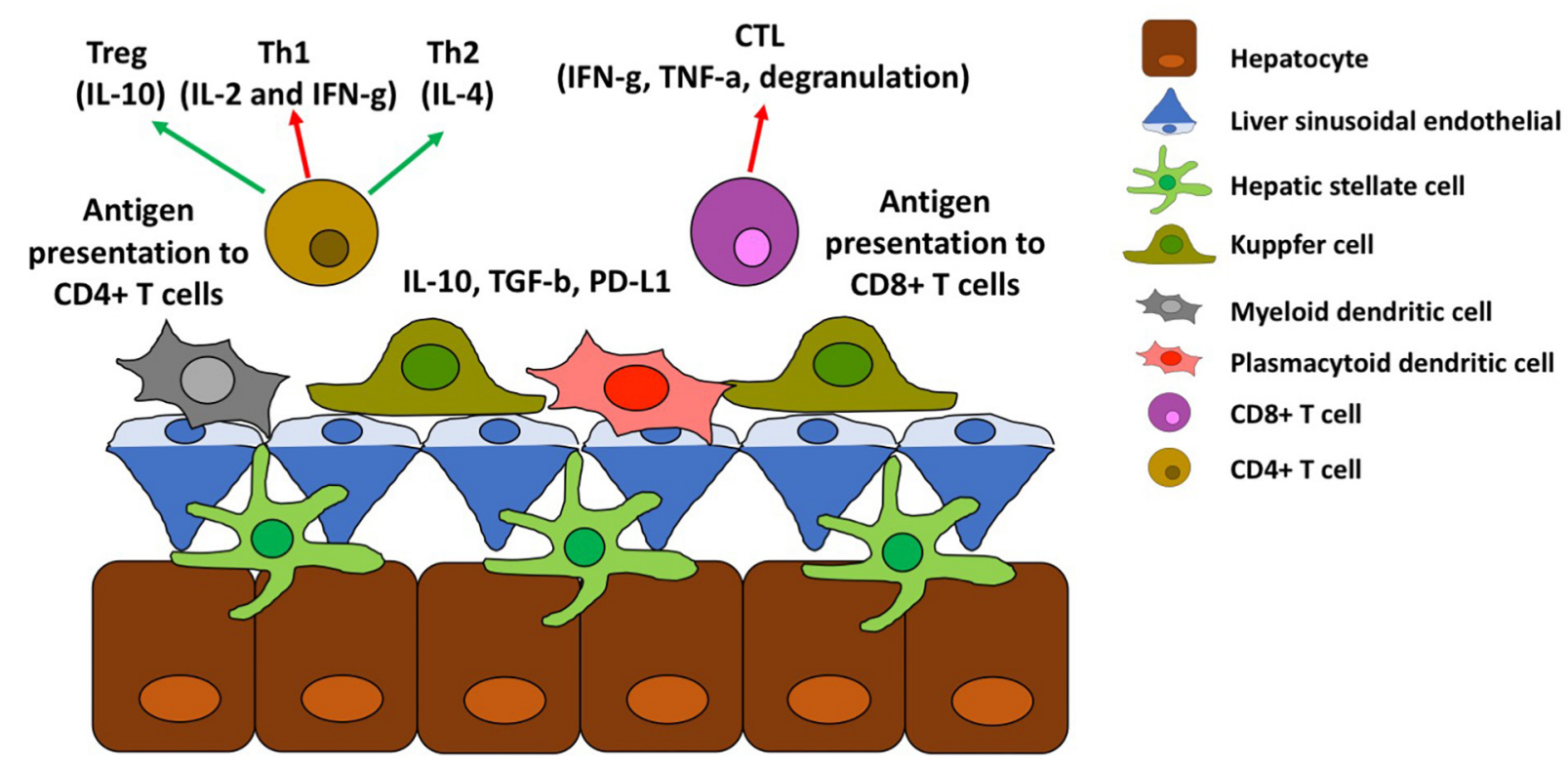

FIGURE 3 | Antigen presentation in the liver. Schematic representation of antigen presentation to CD4+ and CD8+ T cells and its effect toward tolerance (red arrows) or immune activation (green arrow).

clearance is not achieved and the virus is able to persist in the host, this is associated with a chronic inflammation of the liver that can lead to fibrosis, cirrhosis and also cancer. Thus, it is most likely that the persisting hepatic inflammation is the key driver for transformation of hepatocytes to cancer cells. The mechanisms of persistence differs for the different viruses, although a common strategy is to disturb and impair the host immune response. For HBV T cell tolerance, or dysfunction, is a key mechanism of persistence (51). In neonatal vertical infection, the high rate of chronicity is most likely explained by the immature immune response of the host in combination with overproduction of some $\mathrm{HBV}$ proteins. In particular one of these proteins is able to pass the placenta and thereby, when presented during schooling of the immunesystem, is perceived as self proteins $(52,53)$. Hence, these $\mathrm{T}$ cell clones are deleted. Other mechanisms of persistence used by HBV, are the constant presence of viral antigens causing immunactivation and then anergy or dysfunction. Finally, the over production and secretion of HBV surface antigen (HBsAg) particles mainly composed of small HBsAg, effectively blocks neutralizing anti-HBs antibodies. Thus, viral particles whose surface is mainly composed of PreS1 and PreS2 can escape these antibodies and infect new cells. Taken together, these factors most likely explain why HBV is able to persist, despite being a genetically stable virus. In contrast, 
several observations point to the fact that the higher rate of chronic infections due to $\mathrm{HCV}$ as compared to HBV is associated with the better ability of $\mathrm{HCV}$ to evade adaptive immunity (54-56), probably due to its extreme mutation rate (57). Thus, $\mathrm{HCV}$ persists as a virus constantly changing to evade both $\mathrm{B}$ and $\mathrm{T}$ cells. For HDV the mechanisms of persistence are less well known, except that HDV accelerates the tissue damage and disease during dual infection. Chronic hepatitis, regardless of the virus causing it, is characterized by a persistent presence of the viral antigens, which cause a continuous $\mathrm{T}$ cell stimulation. This chronic stimulation is regulated by immune checkpoint (i.e., expression of PD-1) that limit the effector functions of the virusspecific $\mathrm{T}$ cells resulting in a loop of low-grade inflammation and ineffective viral clearance $(58,59)$. Another important actor in the balance between immune activation and suppression are Tregs. Effective viral clearance is achieved through cytotoxicity that can be very dangerous if uncontrolled, or too massive. An excessive tissue damage needs to be prevented for the sake of host survival, and therefore the role of Tregs can be seen as a safe measure against fatal liver injury. Mouse studies modeling acute $\mathrm{HBV}$ infection observed an increased liver damage after Treg depletion (60), also HCV mouse models showed a transient peak of Tregs during acute infection, and a persistent increase in Tregs frequency in chronic infection (61). It is not yet clear wheather Tregs expansion is a cause or a consequence of chronic infection, but certainly this phenomenon is highlighting the complex interplay and immunological balance occurring in the liver during viral infection. The major long-term consequence of chronic infection is the occurrence of fibrosis and cirrhosis that impair liver functionality and also the insurgence of cancer. Treg expansion has been observed in samples of hepatocellular carcinomas (HCCs) and cirrhotic tissue (62). In this study (62), the expression of OX40 (a activation marker) correlates with intratumoral Treg frequency and other markers of proliferation like Ki67; OX40L on the other hand is expressed on myeloid liver infiltrating cells that co-localize with Tregs and directly correlates with HCV viral load. So this is an example of interplay between the host and the virus that is trying to escape the immune system by inducing Tregs via OX40L-OX40 interaction $(63,64)$.

\section{PRIMARY TUMORS IN THE LIVER (HCC)}

Hepatocellular carcinoma is one of the leading causes for cancerrelated death in the world. HCC is mostly asymptomatic and the diagnosis is usually made at a late stage, whereby the prognosis generally is poor. Several risk factors have been identified for HCC, such as chronic viral hepatitis, excessive alcohol consumption, obesity, fatty liver, and diabetes (65). Although the presence of these risk factors aid in monitoring specific patient populations, the molecular mechanism(s) behind tumor initiation, progression, and metastasis are poorly understood and this poses a limitation to find efficient therapeutic approaches.

Hepatocellular carcinoma is associated with the dysregulated growth of hepatocytes that form dysplastic nodules resulting in chronic liver damage or cirrhosis. Mouse models have shown that the hepatocytes in this context have a higher expression of vimentin and type I collagen, suggesting that they are acquiring mesenchymal phenotype (66).

Although the specific mechanism has not been clarified, increasing evidence is pointing at the role of tumor microenvironment in HCC pathogenesis (67). In the following sections we will describe the main cellular components of the liver tumor microenvironment considering the primary tumor but also the metastatic deposits originated from other common tumor types like colon and breast cancer.

\section{MAIN CELLULAR COMPONENTS OF THE TUMOR MICROENVIRONMENT}

\section{Hepatic Stellate Cells (HSCs)}

A summary of cellular components of the tumor microenvironment is represented in Figure 1. These cells are part of the liver connective tissue and are located on the perisinusoidal space. HSCs have many homeostatic functions such as vitamin A accumulation, synthesis of collagen, expression of several soluble factors like cytokines (IL-6, IL-1B) (68), chemokines (CCL5, CCL21) (69), and growth factors (TGFa, TGFb, EGF, PDGF, and bFGF) (70). Liver damage can cause proliferation of HSCs and cytoskeleton remodeling $(71,72)$. When activated HSCs can infiltrate in the HCC stroma (73) and promote tumor vascularization by secreting PDGF that attracts pericytes which also secrete VEGF $(67,74)$.

\section{Cancer-Associated Fibroblasts (CAFs)}

This type of fibroblasts mediates several interactions between the tumor and the liver stroma. They secrete growth factors, cytokines and chemokines (e.g., EGF, FGF, HGF, TGFb, and IL6) that stimulate also tumor growth and proliferation (75), as well as a more malignant phenotype $(76,77)$. Several evidences showed that CAFs play an important role during HCC growth and metastasis $(67,78-80)$.

\section{Endothelial Cells}

The main role of these cells is to promote tissue vascularization. The morphology of blood vessels is different in tumors compared to normal tissues, probably due to increased permeability, and this seems to be related to molecular and functional differences of epithelial cells (81). In particular, the endothelial cells present in the tumor have an accelerated cell cycle, greater migratory abilities and also secrete factors like IL-6, IL-8, MCP-1, and GRO-a that can promote tumor progression and metastasis (67, $82,83)$.

\section{Immune Cells}

\section{Tumor Infiltrating Lymphocytes (TILs)}

Tumor Infiltrating Lymphocytes can play an important role for tumor progression, like Tregs, but can also be the source of powerful anti-tumor cells that can be used for therapy. An immune response against common tumor antigens has indeed been identified from both TIL and blood of HCC patients (84). The presence of Tregs in tumor is usually associated with a worse 
prognosis (85) since this cell type suppress the immune response by inhibiting CD8 $+\mathrm{T}$ cell effector functions like degranulation, and production of perforin and granzymes (86). Recent studies are also highlighting the importance of a mucosal-associated invariant $\mathrm{T}$ cell population (MAIT) that is able to activate and express cytokines (87) and other effector molecules (88), MAIT cells seem also to be negatively affected by chronic viral hepatitis infection (89).

Natural killer cells (NK) account for up to $50 \%$ of the total number of lymphocytes present in the liver. It has been shown that NK have a protective role in the liver especially during chronic viral hepatitis infection even though they are still functionally impaired by HBV and HCV (90). In HCC, it seems that the NK functionality is also impaired but the use of genetically modified NK cells in combination with kinase inhibitors has provided promising results by in vivo models $(91,92)$.

\section{Tumor Associated Macrophages (TAMs)}

Macrophages are frequently found in tumors and according to a high number of clinical and experimental data they seem to promote tumor initiation, progression and even metastasis (93, 94). The mechanism behind the contribution of macrophages to cancer initiation and progression seems to be caused at two major steps: initially macrophages secrete inflammatory molecules like IFN-g, TNF-a and IL-6 in response to chronic infection or irritation and this chronic inflammation seems to be causal to tumor initiation (95). Once the tumor is established, the macrophages switch to an immunosuppressive phenotype promoting progression and malignancy (94). Moreover, TAMs support the metastatic process by promoting tumor cell migration and angiogenesis (94, 96-98). In HCC a role of infiltrating monocytes and KCs seems to be to drive tumor progression and metastasis (99). The presence of TAMs is also associated with increase tumor burden an higher metastasis rate in both HCC patients and mouse models of liver cancer (100). In particular the ability of macrophages to secrete cytokines, chemokines and growth factors seems to be a crucial component of tumor initiation and proliferation $(99,101)$. KCs have a proinflammatory function that seems to be particularly important for HCC initiation (102). At later stages when the tumor is already established their ability to express PD-L1 and secrete immunosuppressive cytokines like IL-10 further contribute to promote tumor progression due to inhibition of effector lymphocytes like CD8+ T cells $(14,103,104)$.

\section{Microenvironment of Metastatic Deposits in the Liver}

As already mentioned the liver receives a massive amount of blood which may help to explain the transport and hepatic entry of metastatic tumor cells coming from other organs of the body. The liver is indeed the main site of metastasis for several types of cancer, like colon, pancreas, melanoma, breast cancer, and sarcomas (105). The same cellular components that play an important role for tumor initiation and progression of primary liver cancer are also likely to be involved in facilitating the establishment of metastasis (106,
107). Another cell type that has been recently shown to be an important player for development of metastasis are marrowderived immune cells recruited to the liver. A mouse model of metastatic pancreatic ductal adenocarcinoma revealed an interplay between the different cellular types in the liver that ultimately favored the metastatic deposit formation (108). In this model, tumor cells secrete exosomes that are taken up by KCs that then increase TGFb production affecting HSC that also increase fibronectin production with ultimate recruitment of bone marrow-derived macrophages. Another study found that exosomes from pancreatic cell lines able to metastasize in the liver, contain integrins that can fuse preferentially with KCs. These data also suggest that exosomes may have a role in disease progression and specific organ metastasis depending on the integrins that they contain (109). In general as a metastatic circulating cell survive the first line of defense offered by KCs and HSC (110), the liver milieu, rich of growth factors, proinflammatory molecule such as S100A8, and immunesuppressive cytokines, favors the formation of pre-metastatic niches $(109,111-114)$. In mouse models, NK cells are shown to play an important role in immune surveillance and prevention or delay of metastatic formation in the liver (115-117). Cancer cells are able to escape direct NK cytotoxicity by forming clusters with other cancer cells (118).

\section{TARGETS FOR THERAPY: CAN WE TILT THE BALANCE?}

As described above the level of complexity of the liver and liver-cancer microenvironment is very high. Due to the multiple cellular components, cytokines, chemokines, and physical disposition around the liver sinusoid, it is unlikely that one single approach could be able to break the vicious loop of inflammation, growth stimulation, and immune-tolerance that characterize the interplay between liver and cancer. Despite this, we believe that a combined approach of several therapies targeting different components of the tumor microenvironment may be effective. In the following sessions the available and potential future therapies for liver cancer are reviewed.

\section{Target Microenvironment With Drugs}

It is possible to specifically block the signaling pathways used by cancer cells to take advantage of the stroma cells and their growth stimulation (119). For HCC the two most studied pathways are the ones that promotes inflammation and angiogenesis (120). The only approved drug for advanced HCC is Sorafenib, a multi-kines inhibitor that target VEGFR, Raf-kinase and PDGFR, but unfortunately its efficacy is limited (121). Other drugs with similar mechanism of action are currently in experimental evaluation $(122,123)$.

\section{Target Microenvironment With Physical Agents}

One curative option for early stage HCC is ablative surgery. If the tumor is removed completely or the liver is transplanted there is a chance that the tumor will not come back. Most of 
patients are unfortunately diagnosed at a very late stage when surgical alternatives are not a possibility anymore (65). Common ablative procedures like radiation, cryoablation, and trans arterial chemoembolization (TACE) are also used at a late stage as palliative treatment. Physically destroying tumor cells may have the advantage to release tumor-antigens that can be taken-up by APCs and be cross-presented to T cells. Increased tumorspecific cytotoxicity has indeed been detected after this type of therapies (124-126). The potential side effect of this treatment is that the presence of PD-L1 on most of APCs in the liver could actually inhibit the tumor-specific T cell response (127) so one obvious measure would be to combine ablation therapy with PD-1 blockade treatment $(128,129)$. This is currently tested in various clinical trials.

\section{Target Microenvironment With Immunotherapy}

Immune suppression and tolerance are key factors in the induction, progression and metastasis of cancer in the liver. It is logical to assume that targeting the immune cells in the liver, reverting what cause their anergic state, may offer a solution for cancer treatment. Several immunotherapy trials have been conducted for HCC with cell therapy (LAK and TIL), cytokines and check-point inhibitors, dendritic cells vaccines and combinations of the above (129). The outcomes of these trials are promising but still not enough to offer a complete remission for HCC. Possibly, the particular microenvironment of the liver presents more challenges compared to other epithelial cancers that were successfully treated by adoptive cell therapy (130-134).

One current promising immunotherapeutic approach is the use of check-point inhibitors that target PD-1 and CTLA-4 promoting $\mathrm{T}$ cell activation (135). Recent clinical trials with the anti-PD-1 monoclonal antibodies Nivolumab showed promising anti-tumor activity in some patients with advanced HCC (136).

\section{CONCLUSION}

In this review we focused on the interplay within the liver between non-parechymal phagocytig and APCs, viruses, and liver

\section{REFERENCES}

1. Josefowicz SZ, Lu LF, Rudensky AY. Regulatory T cells: mechanisms of differentiation and function. Annu Rev Immunol. (2012) 30:531-64. doi: 10.1146/annurev.immunol.25.022106.141623

2. Medzhitov R, Schneider DS, Soares MP. Disease tolerance as a defense strategy. Science. (2012) 335:936-41. doi: 10.1126/science.1214935

3. Rehermann B. Pathogenesis of chronic viral hepatitis: differential roles of $\mathrm{T}$ cells and NK cells. Nat Med. (2013) 19:859-68. doi: 10.1038/nm.3251

4. Racanelli V, Rehermann B. The liver as an immunological organ. Hepatology. (2006) 43(2 Suppl. 1):S54-62.

5. Tiegs G, Lohse AW. Immune tolerance: what is unique about the liver. $J$ Autoimmun. (2010) 34:1-6. doi: 10.1016/j.jaut.2009.08.008

6. Crispe IN. Immune tolerance in liver disease. Hepatology. (2014) 60:2109-17. doi: $10.1002 /$ hep. 27254

7. Doherty DG. Immunity, tolerance and autoimmunity in the liver: a comprehensive review. J Autoimmun. (2016) 66:60-75. doi: 10.1016/j.jaut. 2015.08.020 cancer microenvironments. This highlights the complexity and intricate interplay of different factors. Due to the huge number of antigens going through the liver, the physiological need of having a "safe-guard" mechanism to prevent harmful immuneactivation and liver damage is very understandable. The drawback of this safe-guard mechanism is that pathogens like viruses or cancer, both primary and metastatic tumor cells, may establish and proliferate. We discussed some of the potential targets in the tumor microenvironment that can promote activation for the immune-system and potentially reverse the tolerance against cancer antigens. The milieu in the liver is highly complex and it is probably unrealistic to think that just a single "magic bullet" therapy could tilt the balance an mediate cure. It is most likely necessary to attack many or all the key players to effectively intervene with tumor progression. A combination of physical ablation, immunotherapy and other molecular drugs may indeed be needed.

One of the key components in the tumor microenvironments are TAMs. The biology of macrophages in general is very complex and to some extent still unknown. There are several evidences that suggest a different role of macrophage subgroups depending on their origin (e.g., fetal liver, bone marrow, etc.) and their location in the organism. What is clear is that they can have multiple, and sometimes opposite functions, that can influence clearance or disease progression. More research is needed to better understand the extent of their influence on tumor formation and progression.

\section{AUTHOR CONTRIBUTIONS}

All authors contributed to the conception and the writing of the review.

\section{FUNDING}

This work was supported by Swedish Research Council and Swedish Cancer Society.

8. Schurich A, Berg M, Stabenow D, Böttcher J, Kern M, Schild HJ, et al. Dynamic regulation of CD8 $\mathrm{T}$ cell tolerance induction by liver sinusoidal endothelial cells. J Immunol. (2010) 184:4107-14. doi: 10.4049/jimmunol. 0902580

9. Tay SS, Lu B, Sierro F, Benseler V, McGuffog CM, Bishop GA, et al. Differential migration of passenger leukocytes and rapid deletion of naive alloreactive CD8 T cells after mouse liver transplantation. Liver Transpl. (2013) 19:1224-35. doi: 10.1002/lt.23720

10. Breous E, Somanathan S, Vandenberghe LH, Wilson JM. Hepatic regulatory $\mathrm{T}$ cells and Kupffer cells are crucial mediators of systemic T cell tolerance to antigens targeting murine liver. Hepatology. (2009) 50:612-21. doi: 10.1002/ hep. 23043

11. Kruse N, Neumann K, Schrage A, Derkow K, Schott E, Erben U, et al. Priming of CD4+ T cells by liver sinusoidal endothelial cells induces CD25low forkhead box protein 3- regulatory $\mathrm{T}$ cells suppressing autoimmune hepatitis. Hepatology. (2009) 50:1904-13. doi: 10.1002/hep.23191

12. Heymann F, Peusquens J, Ludwig-Portugall I, Kohlhepp M, Ergen C, Niemietz P, et al. Liver inflammation abrogates immunological tolerance 
induced by Kupffer cells. Hepatology. (2015) 62:279-91. doi: 10.1002/hep. 27793

13. Gomez Perdiguero E, Klapproth K, Schulz C, Busch K, Azzoni E, Crozet L, et al. Tissue-resident macrophages originate from yolk-sac-derived erythromyeloid progenitors. Nature. (2015) 518:547-51. doi: 10.1038/nature13989

14. Krenkel O, Tacke F. Liver macrophages in tissue homeostasis and disease. Nat Rev Immunol. (2017) 17:306-21.

15. Jenne CN, Kubes P. Immune surveillance by the liver. Nat Immunol. (2013) 14:996-1006. doi: 10.1038/ni.2691

16. Thomson AW, Knolle PA. Antigen-presenting cell function in the tolerogenic liver environment. Nat Rev Immunol. (2010) 10:753-66. doi: 10.1038/nri2858

17. Dixon LJ, Barnes M, Tang H, Pritchard MT, Nagy LE. Kupffer cells in the liver. Compr Physiol. (2013) 3:785-97.

18. Eckert C, Klein N, Kornek M, Lukacs-Kornek V. The complex myeloid network of the liver with diverse functional capacity at steady state and in inflammation. Front Immunol. (2015) 6:179. doi: 10.3389/fimmu.2015.00179

19. Tu Z, Bozorgzadeh A, Pierce RH, Kurtis J, Crispe IN, Orloff MS. TLRdependent cross talk between human Kupffer cells and NK cells. J Exp Med. (2008) 205:233-44. doi: 10.1084/jem.20072195

20. Tacke F, Zimmermann HW. Macrophage heterogeneity in liver injury and fibrosis. J Hepatol. (2014) 60:1090-6. doi: 10.1016/j.jhep.2013.12.025

21. Gammella E, Buratti P, Cairo G, Recalcati S. Macrophages: central regulators of iron balance. Metallomics. (2014) 6:1336-45. doi: 10.1039/c4mt00104d

22. Naito M, Hasegawa G, Ebe Y, Yamamoto T. Differentiation and function of Kupffer cells. Med Electron Microsc. (2004) 37:16-28. doi: 10.1007/s00795003-0228-X

23. Wang Y, van der Tuin S, Tjeerdema N, van Dam AD, Rensen SS, Hendrikx T, et al. Plasma cholesteryl ester transfer protein is predominantly derived from Kupffer cells. Hepatology. (2015) 62:1710-22. doi: 10.1002/hep.27985

24. You Q, Cheng L, Kedl RM, Ju C. Mechanism of T cell tolerance induction by murine hepatic Kupffer cells. Hepatology. (2008) 48:978-90. doi: 10.1002/ hep. 22395

25. Erhardt A, Biburger M, Papadopoulos T, Tiegs G. IL-10, regulatory T cells, and Kupffer cells mediate tolerance in concanavalin a-induced liver injury in mice. Hepatology. (2007) 45:475-85.

26. Kinoshita M, Uchida T, Sato A, Nakashima M, Nakashima H, Shono S, et al. Characterization of two F4/80-positive Kupffer cell subsets by their function and phenotype in mice. J Hepatol. (2010) 53:903-10. doi: 10.1016/j.jhep.2010. 04.037

27. Davies LC, Jenkins SJ, Allen JE, Taylor PR. Tissue-resident macrophages. Nat Immunol. (2013) 14:986-95. doi: 10.1038/ni.2705

28. Zhang M, Xu S, Han Y, Cao X. Apoptotic cells attenuate fulminant hepatitis by priming Kupffer cells to produce interleukin-10 through membranebound TGF-beta. Hepatology. (2011) 53:306-16. doi: 10.1002/hep.24029

29. Wu K, Kryczek I, Chen L, Zou W, Welling TH. Kupffer cell suppression of CD8+ T cells in human hepatocellular carcinoma is mediated by B7H1/programmed death-1 interactions. Cancer Res. (2009) 69:8067-75. doi: 10.1158/0008-5472.CAN-09-0901

30. Sun Z, Wada T, Maemura K, Uchikura K, Hoshino S, Diehl AM, et al. Hepatic allograft-derived Kupffer cells regulate $\mathrm{T}$ cell response in rats. Liver Transpl. (2003) 9:489-97.

31. Mosser DM, Edwards JP. Exploring the full spectrum of macrophage activation. Nat Rev Immunol. (2008) 8:958-69. doi: 10.3389/fpls.2013.00334

32. Lawrence T, Natoli G. Transcriptional regulation of macrophage polarization: enabling diversity with identity. Nat Rev Immunol. (2011) 11:750-61. doi: $10.1038 /$ nri3088

33. Bamboat ZM, Stableford JA, Plitas G, Burt BM, Nguyen HM, Welles AP, et al. Human liver dendritic cells promote T cell hyporesponsiveness. J Immunol. (2009) 182:1901-11. doi: 10.4049/jimmunol.0803404

34. Xia S, Guo Z, Xu X, Yi H, Wang Q, Cao X. Hepatic microenvironment programs hematopoietic progenitor differentiation into regulatory dendritic cells, maintaining liver tolerance. Blood. (2008) 112:3175-85. doi: 10.1182/ blood-2008-05-159921

35. Moseman EA, Liang X, Dawson AJ, Panoskaltsis-Mortari A, Krieg AM, Liu YJ, et al. Human plasmacytoid dendritic cells activated by $\mathrm{CpG}$ oligodeoxynucleotides induce the generation of $\mathrm{CD} 4+\mathrm{CD} 25+$ regulatory $\mathrm{T}$ cells. J Immunol. (2004) 173:4433-42.

36. Castellaneta A, Sumpter TL, Chen L, Tokita D, Thomson AW. NOD2 ligation subverts IFN-alpha production by liver plasmacytoid dendritic cells and inhibits their $\mathrm{T}$ cell allostimulatory activity via B7-H1 up-regulation. $J$ Immunol. (2009) 183:6922-32. doi: 10.4049/jimmunol.0900582

37. Haniffa M, Shin A, Bigley V, McGovern N, Teo P, See P, et al. Human tissues contain CD141hi cross-presenting dendritic cells with functional homology to mouse CD103+ nonlymphoid dendritic cells. Immunity. (2012) 37:60-73. doi: 10.1016/j.immuni.2012.04.012

38. Kelly A, Fahey R, Fletcher JM, Keogh C, Carroll AG, Siddachari R, et al. CD141(+) myeloid dendritic cells are enriched in healthy human liver. $J$ Hepatol. (2014) 60:135-42. doi: 10.1016/j.jhep.2013.08.007

39. Limmer A, Ohl J, Kurts C, Ljunggren HG, Reiss Y, Groettrup M, et al. Efficient presentation of exogenous antigen by liver endothelial cells to CD8+ T cells results in antigen-specific T-cell tolerance. Nat Med. (2000) 6:1348-54.

40. von Oppen N, Schurich A, Hegenbarth S, Stabenow D, Tolba R, Weiskirchen $\mathrm{R}$, et al. Systemic antigen cross-presented by liver sinusoidal endothelial cells induces liver-specific CD8 T-cell retention and tolerization. Hepatology. (2009) 49:1664-72. doi: 10.1002/hep.22795

41. Uhrig A, Banafsche R, Kremer M, Hegenbarth S, Hamann A, Neurath $\mathrm{M}$, et al. Development and functional consequences of LPS tolerance in sinusoidal endothelial cells of the liver. J Leukoc Biol. (2005) 77:626-33.

42. Diehl L, Schurich A, Grochtmann R, Hegenbarth S, Chen L, Knolle PA. Tolerogenic maturation of liver sinusoidal endothelial cells promotes B7homolog 1-dependent CD8+ T cell tolerance. Hepatology. (2008) 47:296-305. doi: 10.1002/hep. 21965

43. Charles R, Chou HS, Wang L, Fung JJ, Lu L, Qian S. Human hepatic stellate cells inhibit T-cell response through B7-H1 pathway. Transplantation. (2013) 96:17-24. doi: 10.1097/TP.0b013e318294caae

44. Jiang G, Yang HR, Wang L, Wildey GM, Fung J, Qian S, et al. Hepatic stellate cells preferentially expand allogeneic CD4+ CD25+ FoxP3+ regulatory $\mathrm{T}$ cells in an IL-2-dependent manner. Transplantation. (2008) 86:1492-502. doi: 10.1097/TP.0b013e31818bfd13

45. Yang HR, Chou HS, Gu X, Wang L, Brown KE, Fung JJ, et al. Mechanistic insights into immunomodulation by hepatic stellate cells in mice: a critical role of interferon-gamma signaling. Hepatology. (2009) 50:1981-91. doi: 10. 1002/hep.23202

46. Bertolino P, Trescol-Biemont MC, Rabourdin-Combe C. Hepatocytes induce functional activation of naive CD8+ T lymphocytes but fail to promote survival. Eur J Immunol. (1998) 28:221-36.

47. Qian S, Wang Z, Lee Y, Chiang Y, Bonham C, Fung J. Hepatocyte-induced apoptosis of activated $\mathrm{T}$ cells, a mechanism of liver transplant tolerance, is related to the expression of ICAM-1 and hepatic lectin. Transplant Proc. (2001) 33:226. doi: 10.1016/s0041-1345(00)01985-0

48. Lanini S, Pisapia R, Capobianchi MR, Ippolito G. Global epidemiology of viral hepatitis and national needs for complete control. Expert Rev Anti Infect Ther. (2018) 16:625-39. doi: 10.1080/14787210.2018.1505503

49. Shin EC, Sung PS, Park SH. Immune responses and immunopathology in acute and chronic viral hepatitis. Nat Rev Immunol. (2016) 16:509-23. doi: 10.1038/nri.2016.69

50. Guidotti LG, Inverso D, Sironi L, Di Lucia P, Fioravanti J, Ganzer L, et al. Immunosurveillance of the liver by intravascular effector CD8(+) T cells. Cell. (2015) 161:486-500. doi: 10.1016/j.cell.2015.03.005

51. Park JJ, Wong DK, Wahed AS, Lee WM, Feld JJ, Terrault N, et al. Hepatitis B virus-specific and global T-Cell dysfunction in chronic hepatitis B. Gastroenterology. (2016) 150:684-95.e5. doi: 10.1053/j.gastro.2015.11. 050

52. Chen MT, Billaud JN, Sällberg M, Guidotti LG, Chisari FV, Jones J, et al. A function of the hepatitis B virus precore protein is to regulate the immune response to the core antigen. Proc Natl Acad Sci USA. (2004) 101:14913-8.

53. Chen M, Sällberg M, Hughes J, Jones J, Guidotti LG, Chisari FV, et al. Immune tolerance split between hepatitis B virus precore and core proteins. J Virol. (2005) 79:3016-27.

54. Mutz P, Metz P, Lempp FA, Bender S, Qu B, Schöneweis K, et al. HBV bypasses the innate immune response and does not protect HCV from antiviral activity of interferon. Gastroenterology. (2018) 154:1791-804.e22. doi: 10.1053/j.gastro.2018.01.044

55. Tan A, Koh S, Bertoletti A. Immune response in hepatitis B virus infection. Cold Spring Harb Perspect Med. (2015) 5:a021428. doi: 10.1101/cshperspect. a021428

56. Chen SL, Morgan TR. The natural history of hepatitis C virus (HCV) infection. Int J Med Sci. (2006) 3:47-52. doi: 10.7150/ijms.3.47 
57. Lazarevic I. Clinical implications of hepatitis B virus mutations: recent advances. World J Gastroenterol. (2014) 20:7653-64. doi: 10.3748/wjg.v20. i2 24.7653

58. Barnaba V. Hepatitis $C$ virus infection: a "liaison a trois" amongst the virus, the host, and chronic low-level inflammation for human survival. J Hepatol. (2010) 53:752-61. doi: 10.1016/j.jhep.2010.06.003

59. Guidotti LG, Isogawa M, Chisari FV. Host-virus interactions in hepatitis B virus infection. Curr Opin Immunol. (2015) 36:61-6. doi: 10.1016/j.coi.2015. 06.016

60. Stross L, Günther J, Gasteiger G, Asen T, Graf S, Aichler M, et al. Foxp3+ regulatory $\mathrm{T}$ cells protect the liver from immune damage and compromise virus control during acute experimental hepatitis $\mathrm{B}$ virus infection in mice. Hepatology. (2012) 56:873-83. doi: 10.1002/hep.25765

61. Billerbeck E, Wolfisberg R, Fahnøe U, Xiao JW, Quirk C, Luna JM, et al. Mouse models of acute and chronic hepacivirus infection. Science. (2017) 357:204-8. doi: 10.1126/science.aal1962

62. Piconese S, Timperi E, Pacella I, Schinzari V, Tripodo C, Rossi M, et al. Human OX40 tunes the function of regulatory $\mathrm{T}$ cells in tumor and nontumor areas of hepatitis C virus-infected liver tissue. Hepatology. (2014) 60:1494-507. doi: 10.1002/hep.27188

63. Zhang JY, Wu XL, Yang B, Wang Y, Feng GH, Jiang TJ, et al. Upregulation of OX40 ligand on monocytes contributes to early virological control in patients with chronic hepatitis C. Eur J Immunol. (2013) 43:1953-62. doi: 10.1002/eji.201243097

64. Pollmann J, Götz JJ, Rupp D, Strauss O, Granzin M, Grünvogel O, et al. Hepatitis $\mathrm{C}$ virus-induced natural killer cell proliferation involves monocytederived cells and the OX40/OX40L axis. J Hepatol. (2018) 68:421-30. doi: 10.1016/j.jhep.2017.10.021

65. El-Serag HB. Hepatocellular carcinoma. N Engl J Med. (2011) 365:1118-27.

66. Nitta T, Kim JS, Mohuczy D, Behrns KE. Murine cirrhosis induces hepatocyte epithelial mesenchymal transition and alterations in survival signaling pathways. Hepatology. (2008) 48:909-19. doi: 10.1002/hep.22397

67. Novikova MV, Khromova NV, Kopnin PB. Components of the hepatocellular carcinoma microenvironment and their role in tumor progression. Biochemistry (Mosc). (2017) 82:861-73.

68. Marra F. Chemokines in liver inflammation and fibrosis. Front Biosci. (2002) 7:d1899-914. doi: 10.2741/marra

69. Schwabe RF, Bataller R, Brenner DA. Human hepatic stellate cells express CCR5 and RANTES to induce proliferation and migration. Am J Physiol Gastrointest Liver Physiol. (2003) 285:G949-58.

70. Pinzani M, Marra F, Carloni V. Signal transduction in hepatic stellate cells. Liver. (1998) 18:2-13. doi: 10.1111/j.1600-0676.1998.tb00120.x

71. Friedman SL. Hepatic stellate cells: protean, multifunctional, and enigmatic cells of the liver. Physiol Rev. (2008) 88:125-72. doi: 10.1152/physrev.00013. 2007

72. Kluwe J, Pradere JP, Gwak GY, Mencin A, De Minicis S, Osterreicher CH, et al. Modulation of hepatic fibrosis by c-Jun-N-terminal kinase inhibition. Gastroenterology. (2010) 138:347-59. doi: 10.1053/j.gastro.2009.09.015

73. Wynn TA. Cellular and molecular mechanisms of fibrosis. J Pathol. (2008) 214:199-210.

74. Bergers G, Song S. The role of pericytes in blood-vessel formation and maintenance. Neuro Oncol. (2005) 7:452-64.

75. Pietras K, Ostman A. Hallmarks of cancer: interactions with the tumor stroma. Exp Cell Res. (2010) 316:1324-31. doi: 10.1016/j.yexcr.2010.02.045

76. Jia CC, Wang TT, Liu W, Fu BS, Hua X, Wang GY, et al. Cancerassociated fibroblasts from hepatocellular carcinoma promote malignant cell proliferation by HGF secretion. PLoS One. (2013) 8:e63243. doi: 10.1371/ journal.pone.0063243

77. Liu F, Zhang W, Yang F, Feng T, Zhou M, Yu Y, et al. Interleukin-6-stimulated progranulin expression contributes to the malignancy of hepatocellular carcinoma cells by activating mTOR signaling. Sci Rep. (2016) 6:21260. doi: $10.1038 /$ srep 21260

78. Mazzocca A, Dituri F, Lupo L, Quaranta M, Antonaci S, Giannelli G. Tumor-secreted lysophostatidic acid accelerates hepatocellular carcinoma progression by promoting differentiation of peritumoral fibroblasts in myofibroblasts. Hepatology. (2011) 54:920-30. doi: 10.1002/hep.24485

79. Gaggioli C, Hooper S, Hidalgo-Carcedo C, Grosse R, Marshall JF, Harrington $\mathrm{K}$, et al. Fibroblast-led collective invasion of carcinoma cells with differing roles for RhoGTPases in leading and following cells. Nat Cell Biol. (2007) 9:1392-400.

80. Fransvea E, Mazzocca A, Antonaci S, Giannelli G. Targeting transforming growth factor (TGF)-betaRI inhibits activation of betal integrin and blocks vascular invasion in hepatocellular carcinoma. Hepatology. (2009) 49:839-50. doi: 10.1002/hep.22731

81. Baluk P, Morikawa S, Haskell A, Mancuso M, McDonald DM. Abnormalities of basement membrane on blood vessels and endothelial sprouts in tumors. Am J Pathol. (2003) 163:1801-15.

82. Benetti A, Berenzi A, Gambarotti M, Garrafa E, Gelati M, Dessy E, et al. Transforming growth factor-betal and CD105 promote the migration of hepatocellular carcinoma-derived endothelium. Cancer Res. (2008) 68:862634. doi: 10.1158/0008-5472.CAN-08-1218

83. Knipe L, Meli A, Hewlett L, Bierings R, Dempster J, Skehel P, et al. A revised model for the secretion of tPA and cytokines from cultured endothelial cells. Blood. (2010) 116:2183-91. doi: 10.1182/blood-2010-03276170

84. Flecken T, Schmidt N, Hild S, Gostick E, Drognitz O, Zeiser R, et al. Immunodominance and functional alterations of tumor-associated antigenspecific CD8+ T-cell responses in hepatocellular carcinoma. Hepatology. (2014) 59:1415-26. doi: 10.1002/hep.26731

85. Gao Q, Qiu SJ, Fan J, Zhou J, Wang XY, Xiao YS, et al. Intratumoral balance of regulatory and cytotoxic $\mathrm{T}$ cells is associated with prognosis of hepatocellular carcinoma after resection. J Clin Oncol. (2007) 25:2586-93.

86. Chen W, Jin W, Hardegen N, Lei KJ, Li L, Marinos N, et al. Conversion of peripheral CD4+CD25- naive $\mathrm{T}$ cells to $\mathrm{CD} 4+\mathrm{CD} 25+$ regulatory $\mathrm{T}$ cells by TGF-beta induction of transcription factor Foxp3. J Exp Med. (2003) 198:1875-86.

87. Sobkowiak MJ, Davanian H, Heymann R, Gibbs A, Emgård J, Dias J, et al. Tissue-resident MAIT cell populations in human oral mucosa exhibit an activated profile and produce IL-17. Eur J Immunol. (2019) 49:133-43. doi: 10.1002/eji.201847759

88. Sundström P, Szeponik L, Ahlmanner F, Sundquist M, Wong JSB, Lindskog EB, et al. Tumor-infiltrating mucosal-associated invariant T (MAIT) cells retain expression of cytotoxic effector molecules. Oncotarget. (2019) 10:281023. doi: 10.18632 /oncotarget.26866

89. Dias J, Hengst J, Parrot T, Leeansyah E, Lunemann S, Malone DFG, et al. Chronic hepatitis delta virus infection leads to functional impairment and severe loss of MAIT cells. J Hepatol. (2019) 71:301-12. doi: 10.1016/j.jhep. 2019.04.009

90. Sun C, Sun HY, Xiao WH, Zhang C, Tian ZG. Natural killer cell dysfunction in hepatocellular carcinoma and NK cell-based immunotherapy. Acta Pharmacol Sin. (2015) 36:1191-9. doi: 10.1038/aps.2015.41

91. Kamiya T, Chang YH, Campana D. Expanded and activated natural killer cells for immunotherapy of hepatocellular carcinoma. Cancer Immunol Res. (2016) 4:574-81. doi: 10.1158/2326-6066.CIR-15-0229

92. Hong ZF, Zhao WX, Yin ZY, Xie CR, Xu YP, Chi XQ, et al. Natural killer cells inhibit pulmonary metastasis of hepatocellular carcinoma in nude mice. Oncol Lett. (2016) 11:2019-26.

93. Sica A, Mantovani A. Macrophage plasticity and polarization: in vivo veritas. J Clin Invest. (2012) 122:787-95. doi: 10.1172/JCI59643

94. Qian BZ, Pollard JW. Macrophage diversity enhances tumor progression and metastasis. Cell. (2010) 141:39-51. doi: 10.1016/j.cell.2010.03.014

95. Balkwill FR, Mantovani A. Cancer-related inflammation: common themes and therapeutic opportunities. Semin Cancer Biol. (2012) 22:33-40. doi: 10. 1016/j.semcancer.2011.12.005

96. DeNardo DG, Andreu P, Coussens LM. Interactions between lymphocytes and myeloid cells regulate pro- versus anti-tumor immunity. Cancer Metastasis Rev. (2010) 29:309-16. doi: 10.1007/s10555-010-9223-6

97. Hanahan D, Coussens LM. Accessories to the crime: functions of cells recruited to the tumor microenvironment. Cancer Cell. (2012) 21:309-22. doi: 10.1016/j.ccr.2012.02.022

98. Wynn TA, Chawla A, Pollard JW. Macrophage biology in development, homeostasis and disease. Nature. (2013) 496:445-55. doi: 10.1038/nature12034

99. Ju C, Tacke F. Hepatic macrophages in homeostasis and liver diseases: from pathogenesis to novel therapeutic strategies. Cell Mol Immunol. (2016) 13:316-27. doi: $10.1038 / \mathrm{cmi} .2015 .104$ 
100. Medina-Echeverz J, Eggert T, Han M, Greten TF. Hepatic myeloid-derived suppressor cells in cancer. Cancer Immunol Immunother. (2015) 64:931-40. doi: 10.1007/s00262-015-1736-y

101. Wan S, Kuo N, Kryczek I, Zou W, Welling TH. Myeloid cells in hepatocellular carcinoma. Hepatology. (2015) 62:1304-12. doi: 10.1002/hep.27867

102. Wu J, Li J, Salcedo R, Mivechi NF, Trinchieri G, Horuzsko A. The proinflammatory myeloid cell receptor TREM-1 controls Kupffer cell activation and development of hepatocellular carcinoma. Cancer Res. (2012) 72:3977-86. doi: 10.1158/0008-5472.CAN-12-0938

103. Eggert T, Wolter K, Ji J, Ma C, Yevsa T, Klotz S, et al. Distinct functions of senescence-associated immune responses in liver tumor surveillance and tumor progression. Cancer Cell. (2016) 30:533-47. doi: 10.1016/j.ccell.2016. 09.003

104. Makarova-Rusher OV, Medina-Echeverz J, Duffy AG, Greten TF. The yin and yang of evasion and immune activation in HCC. J Hepatol. (2015) 62:1420-9. doi: 10.1016/j.jhep.2015.02.038

105. Hess KR, Varadhachary GR, Taylor SH, Wei W, Raber MN, Lenzi R, et al. Metastatic patterns in adenocarcinoma. Cancer. (2006) 106:1624-33.

106. Kmiec Z. Cooperation of liver cells in health and disease. Adv Anat Embryol Cell Biol. (2001) 161:1-151.

107. Smedsrød B, Le Couteur D, Ikejima K, Jaeschke H, Kawada N, Naito M, et al. Hepatic sinusoidal cells in health and disease: update from the 14th International Symposium. Liver Int. (2009) 29:490-501. doi: 10.1111/j.14783231.2009.01979.x

108. Costa-Silva B, Aiello NM, Ocean AJ, Singh S, Zhang H, Thakur BK, et al. Pancreatic cancer exosomes initiate pre-metastatic niche formation in the liver. Nat Cell Biol. (2015) 17:816-26.

109. Hoshino A, Costa-Silva B, Shen TL, Rodrigues G, Hashimoto A, Tesic Mark $\mathrm{M}$, et al. Tumour exosome integrins determine organotropic metastasis. Nature. (2015) 527:329-35. doi: 10.1038/nature15756

110. Braet F, Nagatsuma K, Saito M, Soon L, Wisse E, Matsuura T. The hepatic sinusoidal endothelial lining and colorectal liver metastases. World J Gastroenterol. (2007) 13:821-5.

111. Kowanetz M, Wu X, Lee J, Tan M, Hagenbeek T, Qu X, et al. Granulocytecolony stimulating factor promotes lung metastasis through mobilization of Ly6G+Ly6C+ granulocytes. Proc Natl Acad Sci USA. (2010) 107:21248-55. doi: 10.1073/pnas.1015855107

112. Seubert B, Grünwald B, Kobuch J, Cui H, Schelter F, Schaten S, et al. Tissue inhibitor of metalloproteinases (TIMP)-1 creates a premetastatic niche in the liver through SDF-1/CXCR4-dependent neutrophil recruitment in mice. Hepatology. (2015) 61:238-48. doi: 10.1002/hep.27378

113. Zhang Y, Davis C, Ryan J, Janney C, Peña MM. Development and characterization of a reliable mouse model of colorectal cancer metastasis to the liver. Clin Exp Metastasis. (2013) 30:903-18. doi: 10.1007/s10585-0139591-8

114. Brodt P. Role of the microenvironment in liver metastasis: from pre- to prometastatic niches. Clin Cancer Res. (2016) 22:5971-82.

115. Bertin S, Neves S, Gavelli A, Baqué P, Brossette N, Simões S, et al. Cellular and molecular events associated with the antitumor response induced by the cytosine deaminase/5-fluorocytosine suicide gene therapy system in a rat liver metastasis model. Cancer Gene Ther. (2007) 14:858-66.

116. Takehara T, Uemura A, Tatsumi T, Suzuki T, Kimura R, Shiotani A, et al. Natural killer cell-mediated ablation of metastatic liver tumors by hydrodynamic injection of IFNalpha gene to mice. Int J Cancer. (2007) 120:1252-60.

117. Tatsumi T, Takehara T, Yamaguchi S, Sasakawa A, Miyagi T, Jinushi M, et al. Injection of IL-12 gene-transduced dendritic cells into mouse liver tumor lesions activates both innate and acquired immunity. Gene Ther. (2007) 14:863-71.

118. Paschos KA, Majeed AW, Bird NC. Natural history of hepatic metastases from colorectal cancer-pathobiological pathways with clinical significance. World J Gastroenterol. (2014) 20:3719-37. doi: 10.3748/wjg.v20.i14.3719

119. Coulouarn C, Clement B. Stellate cells and the development of liver cancer: therapeutic potential of targeting the stroma. J Hepatol. (2014) 60:1306-9. doi: 10.1016/j.jhep.2014.02.003

120. Taketomi A. Clinical trials of antiangiogenic therapy for hepatocellular carcinoma. Int J Clin Oncol. (2016) 21:213-8. doi: 10.1007/s10147-0160966-0
121. Llovet JM, Ricci S, Mazzaferro V, Hilgard P, Gane E, Blanc JF, et al. Sorafenib in advanced hepatocellular carcinoma. N Engl J Med. (2008) 359:378-90. doi: 10.1056/NEJMoa0708857

122. Montella L, Palmieri G, Addeo R, Del Prete S. Hepatocellular carcinoma: will novel targeted drugs really impact the next future? World J Gastroenterol. (2016) 22:6114-26. doi: 10.3748/wjg.v22.i27.6114

123. Tahmasebi Birgani M, Carloni V. Tumor microenvironment, a paradigm in hepatocellular carcinoma progression and therapy. Int J Mol Sci. (2017) 18:405.

124. Zerbini A, Pilli M, Penna A, Pelosi G, Schianchi C, Molinari A, et al. Radiofrequency thermal ablation of hepatocellular carcinoma liver nodules can activate and enhance tumor-specific T-cell responses. Cancer Res. (2006) 66:1139-46.

125. Mizukoshi E, Yamashita T, Arai K, Sunagozaka H, Ueda T, Arihara F, et al. Enhancement of tumor-associated antigen-specific $\mathrm{T}$ cell responses by radiofrequency ablation of hepatocellular carcinoma. Hepatology. (2013) 57:1448-57. doi: 10.1002/hep.26153

126. Ayaru L, Pereira SP, Alisa A, Pathan AA, Williams R, Davidson B, et al. Unmasking of alpha-fetoprotein-specific CD4(+) $\mathrm{T}$ cell responses in hepatocellular carcinoma patients undergoing embolization. J Immunol. (2007) 178:1914-22.

127. Zeng Z, Shi F, Zhou L, Zhang MN, Chen Y, Chang XJ, et al. Upregulation of circulating PD-L1/PD-1 is associated with poor post-cryoablation prognosis in patients with HBV-related hepatocellular carcinoma. PLoS One. (2011) 6:e23621. doi: 10.1371/journal.pone.0023621

128. Shi L, Chen L, Wu C, Zhu Y, Xu B, Zheng X, et al. PD-1 blockade boosts radiofrequency ablation-elicited adaptive immune responses against tumor. Clin Cancer Res. (2016) 22:1173-84. doi: 10.1158/1078-0432.CCR-15-1352

129. Rai V, Abdo J, Alsuwaidan AN, Agrawal S, Sharma P, Agrawal DK. Cellular and molecular targets for the immunotherapy of hepatocellular carcinoma. Mol Cell Biochem. (2018) 437:13-36. doi: 10.1007/s11010-0173092-Z

130. Rosenberg SA, Yang JC, Sherry RM, Kammula US, Hughes MS, Phan GQ, et al. Durable complete responses in heavily pretreated patients with metastatic melanoma using T-cell transfer immunotherapy. Clin Cancer Res. (2011) 17:4550-7. doi: 10.1158/1078-0432.CCR-11-0116

131. Tran E, Turcotte S, Gros A, Robbins PF, Lu YC, Dudley ME, et al. Cancer immunotherapy based on mutation-specific CD4+ T cells in a patient with epithelial cancer. Science. (2014) 344:641-5. doi: 10.1126/science.1251102

132. Tran E, Robbins PF, Lu YC, Prickett TD, Gartner JJ, Jia L, et al. T-cell transfer therapy targeting mutant KRAS in cancer. N Engl J Med. (2016) 375: $2255-62$.

133. Stevanoviæ S, Pasetto A, Helman SR, Gartner JJ, Prickett TD, Howie B, et al. Landscape of immunogenic tumor antigens in successful immunotherapy of virally induced epithelial cancer. Science. (2017) 356:200-5. doi: 10.1126/ science.aak9510

134. Zacharakis $\mathrm{N}$, Chinnasamy H, Black M, Xu H, Lu YC, Zheng Z, et al. Immune recognition of somatic mutations leading to complete durable regression in metastatic breast cancer. Nat Med. (2018) 24:724-30. doi: 10.1038/s41591018-0040-8

135. Sangro B, Gomez-Martin C, de la Mata M, Iñarrairaegui M, Garralda E, Barrera P, et al. A clinical trial of CTLA-4 blockade with tremelimumab in patients with hepatocellular carcinoma and chronic hepatitis C. J Hepatol. (2013) 59:81-8. doi: 10.1016/j.jhep.2013.02.022

136. Kudo M. Immune checkpoint inhibition in hepatocellular carcinoma: basics and ongoing clinical trials. Oncology. (2017) 92(Suppl. 1):50-62. doi: 10.1159/ 000451016

Conflict of Interest: The authors declare that the research was conducted in the absence of any commercial or financial relationships that could be construed as a potential conflict of interest.

Copyright (c) 2020 Sällberg and Pasetto. This is an open-access article distributed under the terms of the Creative Commons Attribution License (CC BY). The use, distribution or reproduction in other forums is permitted, provided the original author(s) and the copyright owner(s) are credited and that the original publication in this journal is cited, in accordance with accepted academic practice. No use, distribution or reproduction is permitted which does not comply with these terms. 